\title{
A review of the genus Impalaia Mönnig, 1923
}

\section{(Nematoda : Trichostrongyloidea)}

\author{
by Lynda M. GIBBONS *, Marie-Claude DURETTE-DESSET * * \\ and P. DAYNÈS ***
}
* Commonwealth Institute of Helminthology, 103 St. Peter's Street, St. Albans, Herts, England.
** Laboratoire de Zoologie (Vers), Museum national d'Histoire naturelle, 43, rue Cuvier, 75231 Paris Cedex 05 France.
*** P.O. Box 5950, Addis Abeba, Ethiopia.

\section{Summary.}

Four species are considered valid for the genus Impalaia: - I. tuberculata Mönnig, 1923, 1. nudicollis Mönnig, 1931, I. okapiae van den Berghe, 1937 and 1. taurotragi (Le Roux, 1936) Travassos, 1937. I. tuberculata var. longispiculata Wetzel and Fortmeyer, 1960 and I. aegyptiaca Soliman, 1958 are considered synonyms of $I$. tuberculata Mönnig, 1923. I. nudicollis of Daubney, 1933, Yeh, 1956 and Pande et al. 1962 are tentatively considered synonyms of I. tuberculata Mönnig, 1923 and I. dremomys Yen, 1973 is transferred to the genus Heligmonella Mönnig, 1927 and becomes Heligmonella dremomys (Yen, 1973) n. comb. Heligmonella dremomysi Durette-Desset, 1974 becomes Heligmonella moreli nom. nov.

\section{Résumée.}

Révision du genre Impalaia Mönnig, 1923 (Nematoda : Trichostrongyloidea).

Quatre espèces du genre Impalaia sont considérées comme valides : $I$. tuberculata Mönnig, 1923, I. nudicollis, Mönnig, 1931, I. okapiae Van den Berghe, 1937, I. taurotragi (Le Roux, 1936) Travassos, 1937. I. tuberculata var. longispiculata Wetzel et Fortmeyer, 1960 et 1 . aegyptiaca Soliman, 1958 sont considérés comme synomymes de I. tuberculata. 1 . nudicollis sensu Daubney, 1933, sensu Yeh, 1956 et sensu Pande et coll., 1962 sont très probablement synonymes de $I$. tuberculata. $I$. dremomys Yeh, 1973 est transferré dans le genre Heligmonella Mönnig, 1927 et devient Heligmonella dremomys (Yeh, 1973) n. comb. Pour éviter l'homonymie, Heligmonella dremomysi Durette-Desset, 1974 est nommé Heligmonella moreli nom. nov.

Reçu le 25 janvier 1977. 


\section{Introduction}

Mönnig (1923) erected the genus Impalaia for specimens he described and figured from the intestine of Aepyceros melampus from the Transvaal, South Africa. Later (1924), he referred to the new genus Impalaia with 1 . tuberculata as type species, without including any description or illustrations. Yorke and Maplestone (1926) described and redrew I. tuberculata. Mönnig (1931) added the species $I$. nudicollis from the small intestine of Damaliscus albifrons from Pretoria Zoo in South Africa and included a description of the infective larvae of this species. Le Roux (1936) erected the genus Minutostrongylus, with $M$. taurotragi as type, recovered from the duodenum of Taurotragus oryx from near Mazabuka, Northern Rhodesia but Travassos (1937) synonymised this genus with the genus Impalaia. Yamaguti (1961) did not accept Travassos's synonymy. Daubney (1933) described Impalaia nudicollis in the abomasum and small intestine of Ovis aries from Mpapwa, Tanzania and Rift Valley and Athi Plain, Kenya and differentiated it from 1 . tuberculata by the length of the dorsal ray and spicules and the absence of tubercles in the cervical region. Soliman (1958) described the species I. aegyptiaca for specimens from the small intestine of Camelus dromedarius in Cairo, Egypt. Yeh (1956) reported and described I. nudicollis in the duodenum of Gazella thomsonii from Loliondo and Banagi regions, Tanzania. Wetzel and Fortmeyer (1960) described some specimens from Lithocranius walleri in the Frankfurt Zoological Gardens, West Germany as Impalaia tuberculata var. longispiculata which Round (1968) synonymised as $I$. tuberculata. Pande, Rai and Bhatia (1962) redescribed Impalaia nudicollis from specimens found in the intestine of camel from India. Croveri (1929) erected the genus Anthostrongylus for A. somalilensis from the intestine of a dromedary in Somalia. Travassos (1937) compared the description of $A$. somalilensis with Impalaia tuberculata and considered it a synonym of $I$. tuberculata and in the same year van den Berghe (1937) added the species Anthostrongylus okapiae from the small intestine of Okapia johnstoni from Epulu (Ituri, Belgian Congo). Pande et al. (1962), in their discussion of the two genera, agreed with Travassos's synonymy and transferred Anthostrongylus okapiae to Impalaia as a new combination. Durette-Desset (1972) described and figured the synlophe of Impalaia tuberculata and $I$. nudicollis and differentiated the two species. Yen (1973) added $I$. dremomys to the genus from the small intestine of Dremomys $r$. rufigens in Fenchiang Yunnan Province, China.

\section{I. - Redescription of the species}

Impalaia tuberculata Mönnig, 1923.

Material: 1 ot, 1 (types) Onderstepoort helminth collection No. 2100.

Host: Aepyceros melampus Licht. 

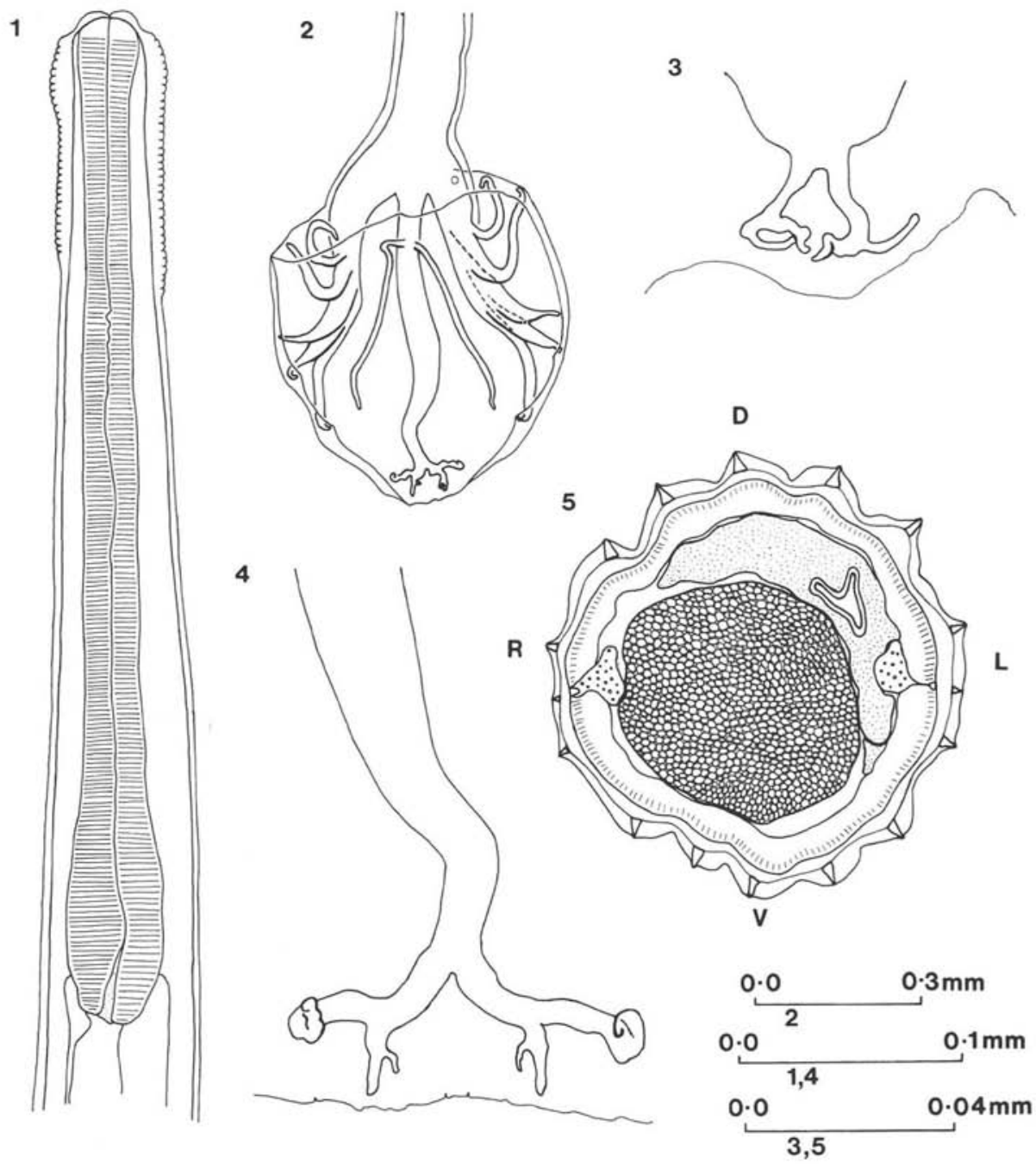

FIG. 1. - Impalaia tuberculata:

1. 2, 3 from Giraffa camelopardalis; 4 from Rhynchotragus kirkii; 5 from Gazella thomsonii. 1. Anterior end of male. 2. Bursa, ventral view. 3. Genital cone, ventral view. 4. Distal end of dorsal ray. 5. Cross section of male.

Habitat: intestine.

Locality: Transvaal, South Africa.

Other material: 6 o, 8 from the small intestine of Taurotragus oryx in the Serengeti region, Tanzania collected by Dr. R. Sachs, $2 \sigma^{*}, 2 q$ from the small intestine of 
6 a
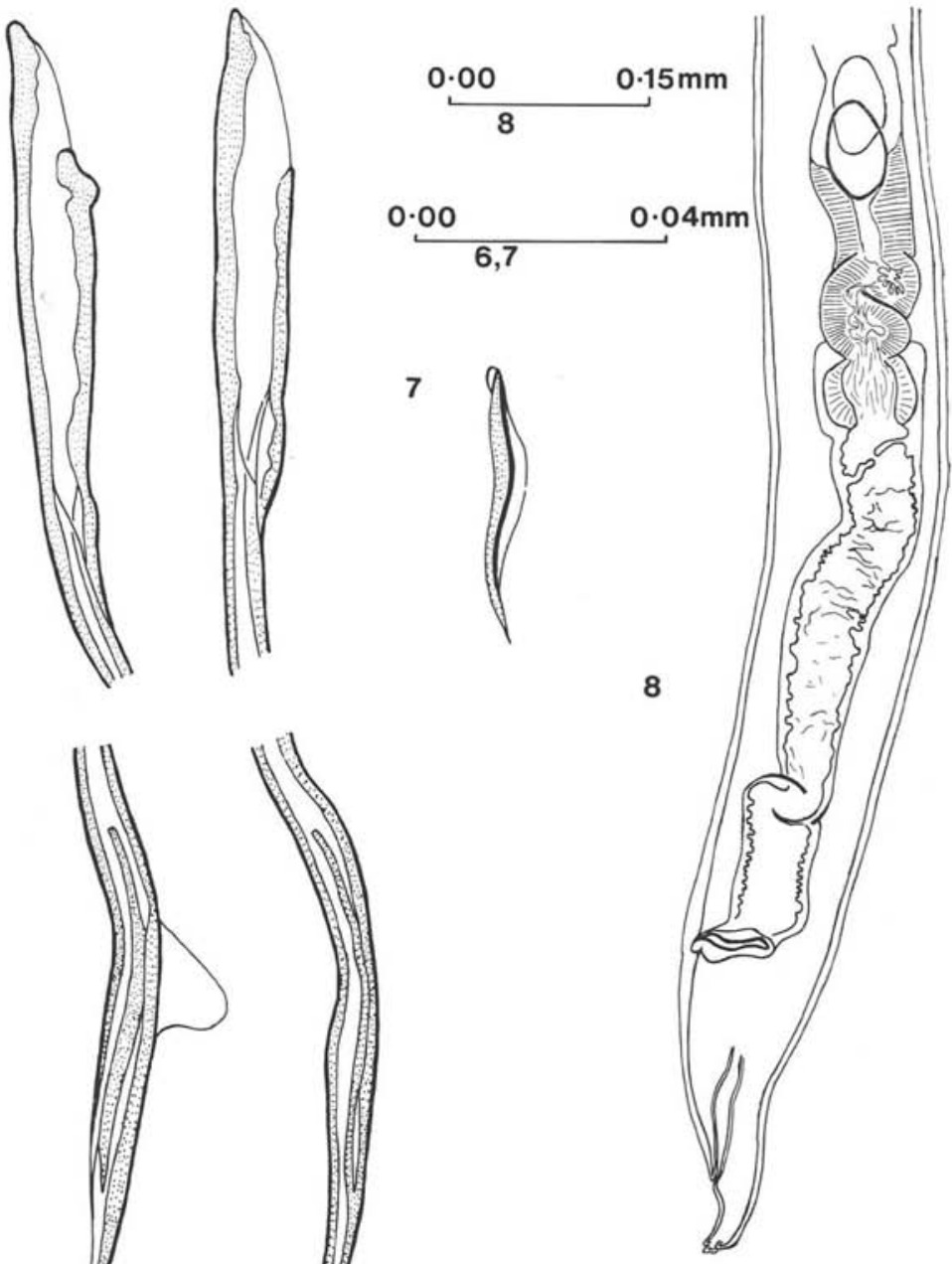

b
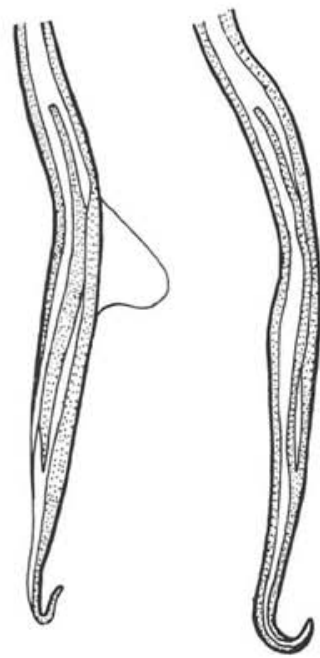

FIG. 2. - Impalaia tuberculata:

6, 7 from Giraffa camelopardalis; 8 from Rhynchotragus kirkii. 6. Spicules: a. proximal end, $b$. distal end. 7. Gubernaculum. 8. Posterior end of female.

Aepyceros melampus Suguroi Estate, Kenya and $1 \delta^{*}, 1+$ from the small intestine Gazella thomsonii Gilgil, Kenya collected by Dr. J. Grootenhuis, $3 \delta$ from the small intestine of Giraffa camelopardalis in Marwell Zoological Park, England collected by Mr. Scudamore, $1 \sigma^{\star}$ from Camelus dromedarius in Agadis, Niger collected by Dr. R. 
Delavenay, M.N.H.N. Paris No. 51 MA, numerous $\delta$ and $q$ from the same host species collected by Dr. Daynès in the slaughterhouses of Negele Borana, Addis-Abeba, Ethiopia, M.N.H.N. Paris No. $380 \mathrm{CA}$ and $381 \mathrm{CA}$.

Redescription (fig. 1, 2, 3).

Synlophe: in both sexes there are 16 symmetrically arranged longitudinal cuticular ridges.

Male: body $7.90-9.81 \mathrm{~mm}$ long, $0.103-0.169 \mathrm{~mm}$ wide anterior to bursa. Cephalic vesicle $0.106-0.134 \times 0.035-0.054 \mathrm{~mm}$. "Tubercles" present only on type male. Excretory pore and cervical papillae are $0.362-0.555$ and $0.359-0.457 \mathrm{~mm}$ from the anterior end respectively. Esophagus 0.437-0.512 mm long. Nerve ring not seen. Prebursal papillae present. Spicules alate, $0.920-1.32 \mathrm{~mm}$ long with slightly curved, pointed ends and with a transparent knob, 0.049-0.066 mm from the distal end of one spicule, not seen in the type specimen as the spicules were withdrawn within the body. Gubernaculum 0.076-0.107 mm long. Dorsal ray $0.495-0.640 \mathrm{~mm}$ long. Genital cone with two bifid rays.

Female: body $11.28-17.64 \mathrm{~mm}$ long, $0.089-0.165 \mathrm{~mm}$ wide at level of vulva. Cephalic vesicle $0.095-0.115 \mathrm{~mm} \times 0.035-0.044 \mathrm{~mm}$. "Tubercles" present only on type female. Excretory pore opens $0.409-0.534 \mathrm{~mm}$ from anterior end. Cervical papillae and nerve ring not seen. Esophagus $0.432-0.531 \mathrm{~mm}$ long. Monodelphic. Ovejector including sphincter 0.348-0.611 mm long. Distal muscular section of uterus anterior to sphincter $0.183-0.280 \mathrm{~mm}$ long. Eggs, in ovejector, $0.059-0.074 \times 0.031-0.046 \mathrm{~mm}$. Vulva $0.188-0.240 \mathrm{~mm}$ from the posterior end. Tail $0.031-0.060 \mathrm{~mm}$ long and has one terminal and two subterminal papillae.

Impalaia nudicollis Mönnig, 1931.

Material : $4 \delta^{\star}, 5 q$ collected by Mönnig, London School of Hygiene and Tropical Medicine collection* No. 236.

Host: Damaliscus albifrons Burch.

Habitat: unknown.

Locality: South Africa.

Redescription (fig. 3-4).

Synlophe: a female was sectioned and examined. There are 16 symmetrically arranged longitudinal cuticular ridges similar to the type species $I$. tuberculata.

Male: body $4.95-7.48 \mathrm{~mm}$ long, $0.082-0.108 \mathrm{~mm}$ wide anterior to bursa. Cephalic vesicle $0.082-0.122 \times 0.033-0.043 \mathrm{~mm}$. Excretory pore and nerve ring are $0.292-0.451$ and $0.210 \mathrm{~mm}$ from the anterior end respectively. Cervical papillae not seen. Oesophagus 0.251-0.365 mm long. Prebursal papillae present. Spicules, alate, 0.81-0.86 mm long with pointed tips. Gubernaculum $0.074-0.089 \mathrm{~mm}$ long. Dorsal ray 0.225-0.231 mm long. Genital cone with two undivided rays.

(*) Collection now housed at the Commonwealth Institute of Helminthology, St. Albans, Herts, England. 


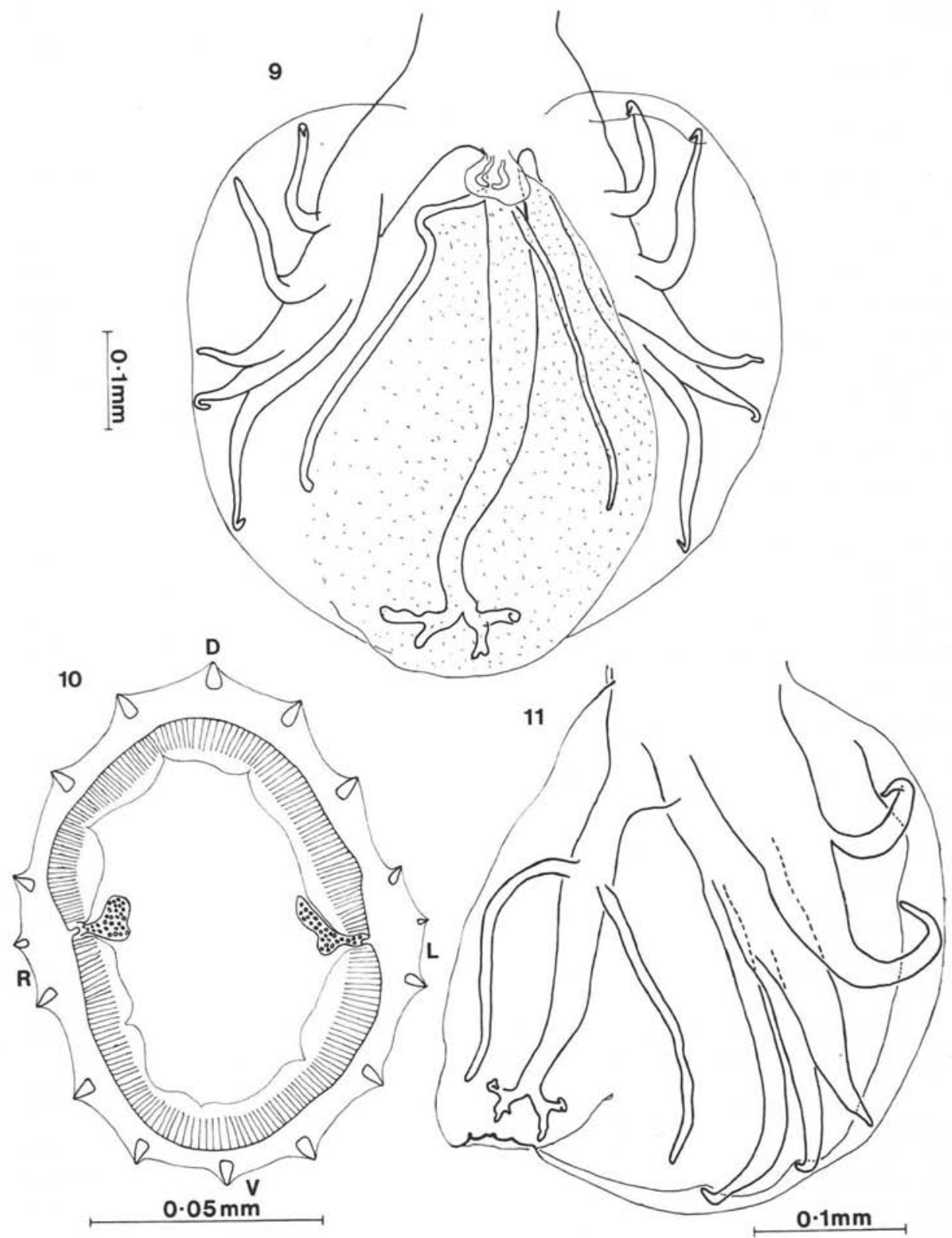

FIg. 3. - Impalaia tuberculata from Camelus dromedarius: 9. Bursa. 10. Cross section of male. Impalaia nudicollis from Damaliscus albifrons: 11. Bursa, dorsal view. 
Female: body $11.65-12.89 \mathrm{~mm}$ long, $0.083-0.094 \mathrm{~mm}$ wide at the level of the vulva. Cephalic vesicle $0.093-0.125 \times 0.036-0.047 \mathrm{~mm}$. Excretory pore and cervical papillae are $0.432-0.453$ and $0.437-0.449 \mathrm{~mm}$ from the anterior end respectively. Nerve ring could not be seen. Oesophagus $0.306-0.362 \mathrm{~mm}$ long. Monodelphic. Ovejector including sphincter 0.141-0.235 mm long. Distal muscular section of uterus anterior to sphincter 0.084$0.120 \mathrm{~mm}$ long. Eggs, in uterus, $0.038-0.055 \times 0.029-0.033 \mathrm{~mm}$. Vulva $0.207-0.249 \mathrm{~mm}$ from the posterior end. Tail $0.048-0.065 \mathrm{~mm}$ long and appears to have a single terminal and two subterminal papillae.

Impalaia taurotragi (Le Roux, 1936) Travassos, 1937.

Material: fragments of $2 \widehat{\delta}, 1$ (types) London School of Hygiene and Tropical Medicine collection* Nos. 187-189.

Host: Taurotragus oryx Pallas.

Habitat: duodenum.

Locality: Northern Rhodesia.

Redescription (fig. 5).

Synlophe: all the fragments are permanently mounted on slides and no further specimens are available for sectioning.

Few measurements are available as the specimens are fragmented.

Male: spicules, alate, $0.569-0.590 \mathrm{~mm}$ long with pointed tips. Gubernaculum $0.065 \mathrm{~mm}$ long. Prebursal papillae present. Dorsal ray $0.047 \mathrm{~mm}$ long. Genital cone with two rays, which bifurcate close to the distal end.

Female: monodelphic. Ovejector including sphincter $0.333 \mathrm{~mm}$ long. Distal muscular section of the uterus not clear. Eggs, in ovejector, $0.075 \times 0.033 \mathrm{~mm}$. Vulva $0.170 \mathrm{~mm}$ from posterior end. Tail $0.050 \mathrm{~mm}$ long with one terminal and two subterminal papillae.

\section{II. - Discussion}

According to Mönnig (1923) the type species Impalaia tuberculata has numerous irregularly arranged tubercles on the anterior end and its spicules are $0.60 \mathrm{~mm}$ long with bifid proximal ends. However, Mönnig (1932) considered these tubercles to be artefact and distinguished this species from 1 . nudicollis by its shorter spicules, its larger bursa and dorsal ray. Examination of the type male of $I$. tuberculata showed that the spicules are $0.920 \mathrm{~mm}$ long and do not have bifid ends, suggesting the possibility that the spicule length of $0.6 \mathrm{~mm}$ given in the original description is a printing error.

Travassos (1937) synonymised Anthostrongylus somalilensis with I. tuberculata on the basis of the morphology of the dorsal ray but Baer (1950), did not accept this synonymy because of the differences in size of the spicules and eggs of the two species. 

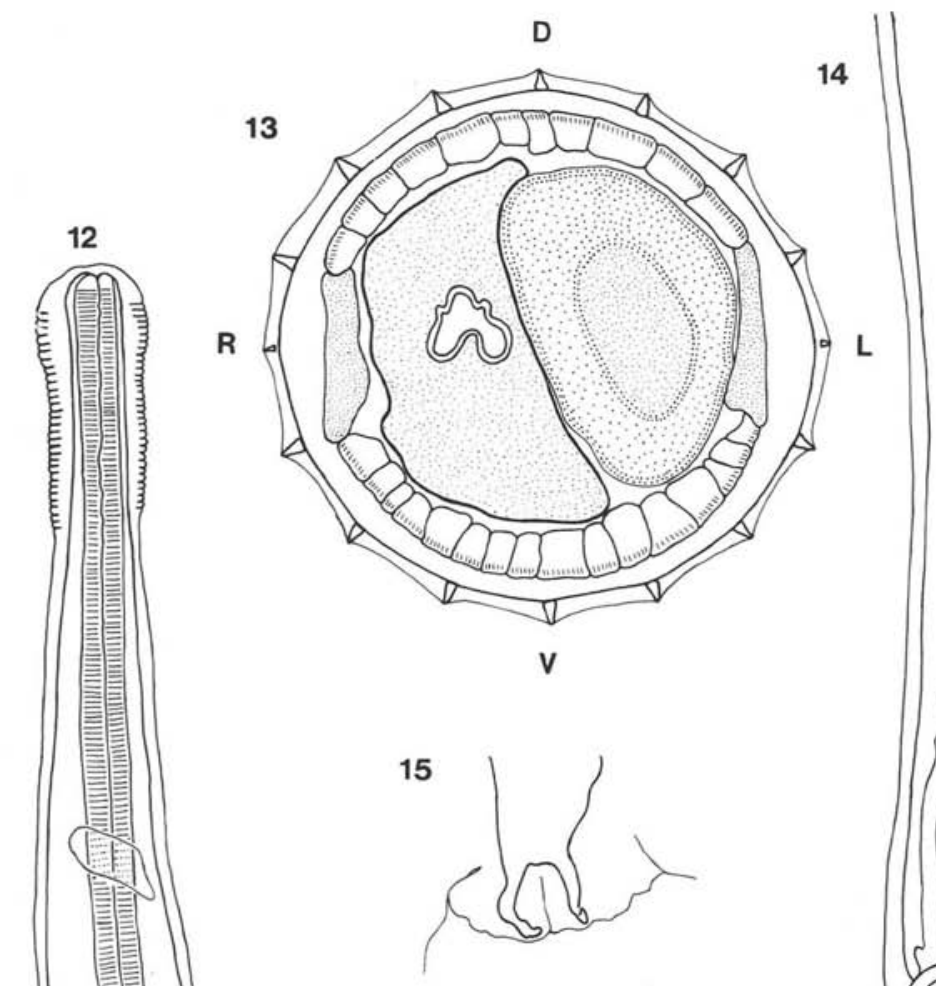

16

a
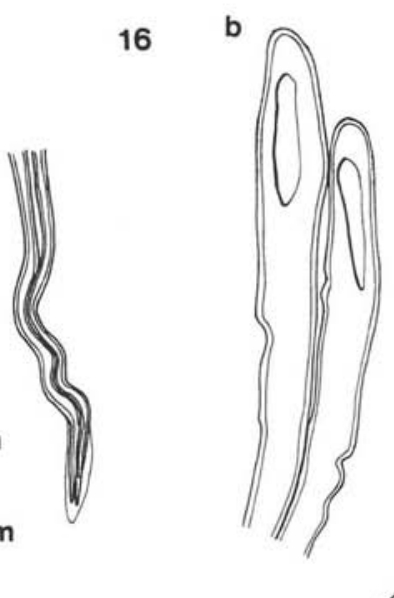

FIG. 4. - Impalaia nudicollis from Damaliscus albifrons:

12. Anterior end of male. 13. Cross section of female. 14. Posterior end of female. 15. Genital cone. 16. Spicules : $a$. distal end, $b$. proximal end. 


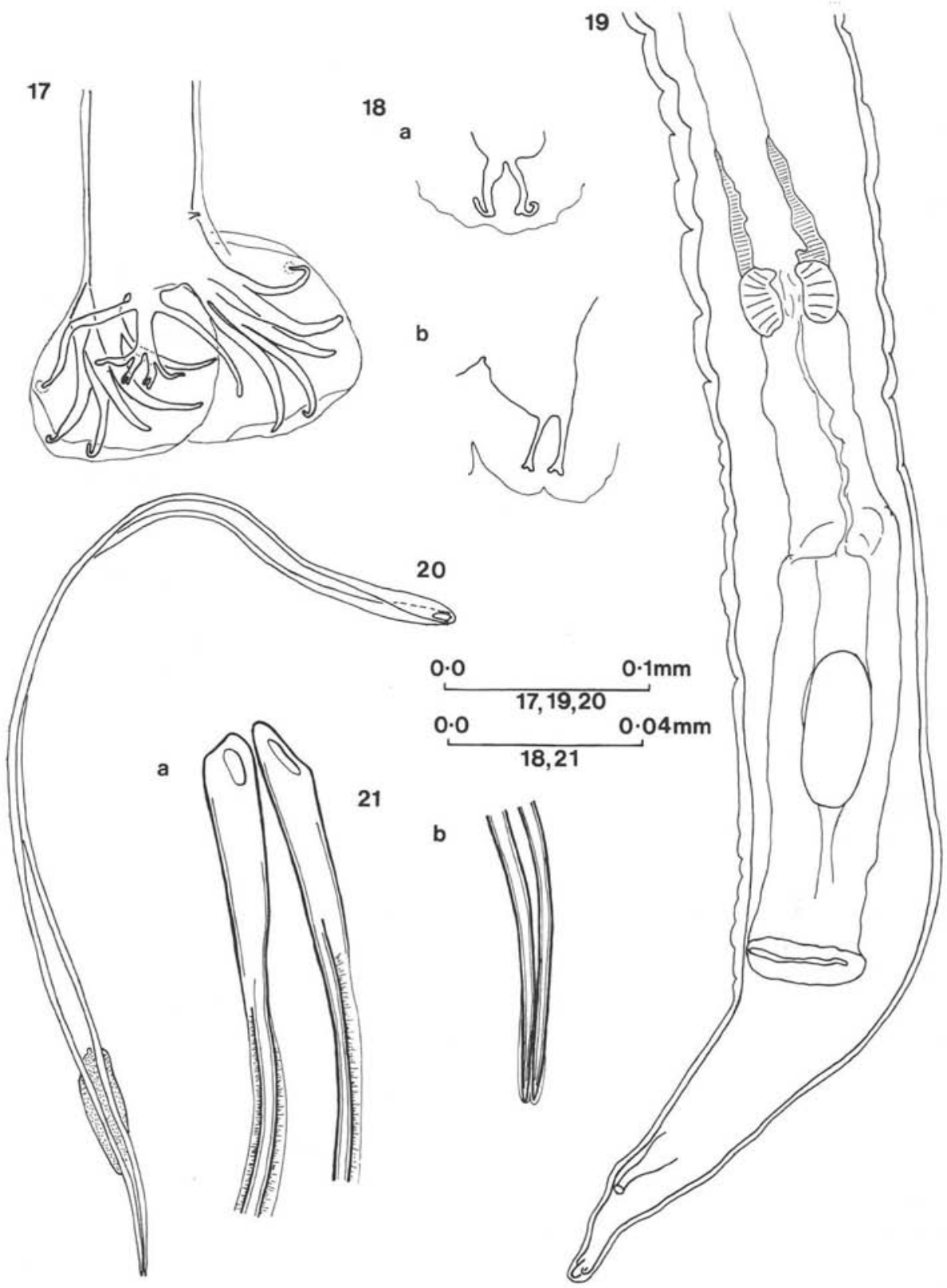

FIG. 5. - Impalaia taurotragi from Taurotragus oryx:

17. Bursa. 18. Genital cone, dorsal view. 19. Posterior end of female. 20. Spicules. 21. Spicules: $a$. proximal end, $b$. distal end. 
A comparison of the measurements and synlophe of material collected from the same host species Camelus dromedarius from Ethiopia, a geographical locality near to the original locality, Somalia confirms Travassos's synonymy.

According to Yamaguti, 1961 the genus Minutostrongylus Le Roux, 1936 should be maintained as a separate genus from Impalaia as its type species has a short dorsal ray and an uncoiled body. Re-examination of the type species shows that the morphological characters of both the male and female are similar to those described for the genus Impalaia and Travassos's synonymy of 1937 is accepted.

Daubney (1933), Yeh (1956) and Pande et al. (1962) redescribed I. nudicollis and from their descriptions, the size of the bursa, length of the spicules and morphology of the females are very similar to those described here for I. tuberculata. As the specimens described by these authors were not available for re-examination they can only tentatively be assigned to $I$. tuberculata.

I. tuberculata var. longispiculata was erected by Wetzel and Fortmeyer (1960) for specimens with a greater spicule length than I. tuberculata Mönnig, 1923. The spicule length of $0.838-1.202 \mathrm{~mm}$ comes within the range for this species as described here and the synonymy of the variety by Round (1968) is confirmed.

Soliman (1958) considered his I. aegyptiaca a new species « until the range of variability in the previously mentioned species (I. tuberculata, I. nudicollis) is more accurately studied and a comparative examination of the original type specimens , made. He distinguished his species from those previously described by the greater spicule length, the presence of a sclerotised knob-like structure joining the spicules near their distal ends and the greater length of the dorsal ray. Comparison of the types of this species with $I$. tuberculata has shown that these characters together with the morphology of the females are similar in both species and consequently $I$. aegyptiaca is considered here as a synonym of $I$. tuberculata Mönnig, 1923.

Impalaia okapiae was distinguished by van den Berghe (1937) from Anthostrongylus somalilensis by the presence of 14 longitudinal cuticular ridges, greater length of spicules and the position of the posterolateral ray in relation to the other lateral rays. Baer (1950) in his study of the parasites of the okapi commented that the size of the spicules and eggs immediately distinguished $I$. somalilensis and $I$. okapiae from the other species. However, in the absence of material he was unable to comment any further on the position of these two species. Although no specimens of $I$. okapiae could be traced for this study the size of the spicules and eggs confirm its validity.

Although the types of Impalaia dremomys Yen, 1973, from Dremomys $r$. rufigens in China are not available for examination, from the description the structure of the dorsal ray and lobe separate it from the other species of Impalaia and suggest that it should be placed in a different genus. It is very close to the species Heligmonella dremomysi Durette-Desset, 1974, described from Dremomys lokriah in Nepal and is transferred to the genus Heligmonella as Heligmonella dremomys. Heligmonella dremomysi Durette-Desset, 1974, now becomes a homomyn of Yen's species and a new name Heligmonella moreli is proposed in honour of Dr. Morel. H. dremomys can be 
distinguished from $H$. moreli by the body length, the size of the spicules and the width of the bursal rays.

\section{Key to the species of the genus Impalaia}

1. Males with transparent knob on one spicule:

Dorsal ray $0.495-0.640 \mathrm{~mm}$ long and distinctly curved near its distal end. Genital cone with two bifid rays.

Female tail narrow

I. tuberculata

Males without transparent knob on one spicule.

2. Males with spicules over $1 \mathrm{~mm}$ long:

Posterolateral ray thin, separated from the other lateral rays.

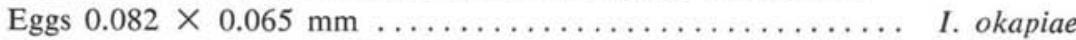

3. Males with spicules under $1 \mathrm{~mm}$ long:

Dorsal ray $0.225-0.231 \mathrm{~mm}$ long and straight.

Spicules 0.81-0.86 mm long.

Genital cone with two individed rays.

Female tail broad $\ldots \ldots \ldots \ldots \ldots \ldots \ldots \ldots \ldots \ldots \ldots \ldots \ldots \ldots$ I. nudicollis

Dorsal ray $0.047 \mathrm{~mm}$ long.

Spicules 0.569-0.590 mm long.

Genital cone with two rays which bifurcate only near their distal ends ....

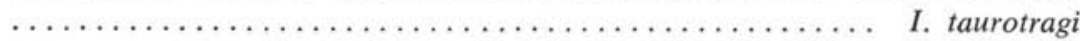

\section{ACKNOWLEDGMENTS}

The authors are grateful to Dr. A. Verster and Dr. D. Gibson for sending type material from the Onderstepoort Helminth Collection and British Museum (Natural History) Collection respectively, Dr. R. Sachs, Dr. J. Grootenhuis and Mr. Scudamore for making specimens available for this study and to Dr. S. Willmott and Dr. L. F. Khalil for their constructive criticism of the draft manuscript.

\section{References}

Baer (J.-G.), 1950. - Etude critique des helminthes parasites de l'okapi. Acta Tropica, 7, 164-186.

Berghe (L. van den), 1937. - Contribution à l'étude des parasites de l'okapi (troisième partie). Rev. Zool. Bot. Afr. Belgium, 30, 117-139.

Croveri (P.), 1929. - Un nuovo strongylide: Anthostrongylus somalilensis Croveri, 1917 (n.g. n.s.) Parassita dei dromedari somali a la strongilosi intestinale epizootica dei dromedari: Ber Cursu. Arch. Ital. Sci. Med. Coloniali, 10, 145-171. 
Daubney (R.), 1933. - Trichostrongylid nematodes from sheep in Kenya. Parasitology, 25, 224-241.

DuREtTe-Desset (M.-C.), 1972. - Compléments à l'étude morphologique de quelques Nématodes Héligmosomes parasites de Rongeurs et de Ruminants. Bull. Mus. Nat. Hist. Nat. Zool., $3^{\circ}$ série, 42, Zool., 36, 501-508.

Durette-Desset (M.-C.), 1974. - Description de deux nouveaux Nématodes Héligmosomes chez un Sciuridé (Dremomys lokriah) du Népal. Bull. Mus. Nat. Hist. Nat. 3e série, 232, Zool., 156, 819-825.

LE Roux (P. L.), 1936. - A new trichostrongylid (Minutostrongylus taurotragi g. et sp. n.) of the subfamily Heligmosominae from an african antilope. J. Helminthol., 14, 73-76.

MönNIG (H. O.), 1923. - On some new South African parasitic nematodes. Trans. R. Soc. S. Africa, II, 105-117.

MöNNIG (H. O.), 1924. - South African parasitic nematodes. 9th and 10th Reports of the Director of Veterinary Education and Research, Department of Agriculture, Pretoria, Union of South Africa, 435-478.

MöNNIG (H. O.), 1931. - Wild antelopes as carriers of nematode parasites of domestic ruminants. Part I. 17th Report of the Director of Veterinary Services and Animal Industry. Union of South Africa, 233-254.

MöNNIG (H. O.), 1932. - Wild antelopes as carriers of nematode parasites of domestic ruminants. Part II. 18th Report of the Director of Veterinary Services and Animal Industry, Union of South Africa, 153-172.

Pande (B. P.), Rai (P.) et Bhatia (B. B.), 1962. - On two new records of trichostrongylid and a heligmosomatid nematode hitherto unknown from Camelus dromedarius L. in India with remarks on the genus Impalaia Mönnig. Indian J. Veterinary Science Animal Husbandry, 32 (1), 27-32.

Round (M. C.), 1968. - Checklist of the helminth parasites of african mammals of the orders Carnivora, Tubulidentata, Proboscidea, Hyracoidea, Artiodactyla and Perissodactyla. Tech. Com. Commonw. Bur. Helminthol., $\mathrm{n}^{\circ} 38, \mathrm{vi}+252$ pp.

Soliman (K. N.), 1958. - On a new species of the nematode genus Impalaia from the camel (Camelus dromedarius) in Egypt. Br. Vet. J., 112, 507-512.

Travassos (L.), 1937. - Revisão da familia Trichostrongylidae Leiper, 1912. Monographias do Instituto Oswaldo Cruz, 1, 512 pp.

Wetzel (R.) et ForTmeYer (H. P.), 1960. - Zur kenntnis von Impalaia tuberculata Mönnig, 1924. Z. Parasitenkd', 20, 138-145.

YamagutI (S.), 1961. - Systema Helminthum, vol. III. The nematodes of vertebrates. New York and London: Interscience Publishers, vi $+1261 \mathrm{pp}$.

YEH (L.S.), 1956. - On a collection of helminths from Thomson's gazelle, Gazella thomsonii, from Tanganyika. J. Helminthol., 29, 203-228.

YEN (W. C.), 1973. - Helminths of birds and wild animals from Lin-tsan Prefecture, Yunnan Province, China II. Parasitic nematodes of mammals. Acta Zool. Sinica, $19,354-364$.

YoRKe (W.) and MAPLESTONE (P. A.), 1926. - The nematode parasites of vertebrates. J. and A. Churchill, edit., London, 536 p. 